\title{
RELATIVE EFFICACY OF INTRAVENOUS IRON VERSUS ORAL IRON ON INCREASING HEMOGLOBIN LEVEL AMONG PREGNANT WOMEN WITH IRON DEFICIENCY ANEMIA: A META-ANALYSIS
}

\author{
Fiki Cahya Ningrum ${ }^{1)}$, Bhisma Murtii ${ }^{1}$, Vitri Widyaningsih'²) \\ ${ }^{1)}$ Masters Program in Public Health, Universitas Sebelas Maret \\ 2) Faculty of Medicine, Universitas Sebelas Maret
}

\begin{abstract}
Background: Iron deficiency is a major cause of anemia in pregnancy. Iron deficiency anemia in pregnancy can lead hematological disorders and complication both in the mother and fetus. This study aimed to compare the efficacy of intravenous iron and oral iron administration for iron deficiency treatment in among pregnant women.

Subjects and Method: This was a meta-analysis using PRISMA systematic guideline. Published articles from years 2000 to 2008 were collected from PubMed, Science Direct, Springer Link, and Google Scholar databases. There were 9 articles met randomized controlled trial (RCT) criteria. A sample of 1,075 was divided into two groups, 537 in intravenous iron and 538 oral iron. Mean Difference and heterogenity test were analyzed by Review Manager (RevMan) 5.3 software program.

Results: Intravenous iron administration increased hemoglobin level $0.65 \mathrm{~g} / \mathrm{dL}$ higher than oral iron administration (Mean Difference $=0.65 ; 95 \% \mathrm{CI}=0.38$ to 0.92 ; $\mathrm{p}<0.001$ ).

Conclusion: Intravenous iron administration is more effective to raise hemoglobin level than oral iron administration.
\end{abstract}

Keywords: anemia, pregnancy, iron deficiency, meta-analysis, intravenous iron

\section{Correspondence:}

Fiki Cahya Ningrum. Masters Program in Public Health, Universitas Sebelas Maret. Jl. Ir. Sutami 36A, Surakarta 57126, Central Java. Email: ningrum.fiki@gmail.com. Mobile: 081216494956 